\title{
Models of Enterpreneurship Education in Elementary School
}

\author{
Faris Nur Khulafa \\ Universitas Negeri Semarang, Semarang, Indonesia \\ Corresponding e-mail: khulafafaris@gmail.com
}

\begin{abstract}
The ASEAN Economic Community or the MEA took effect on 1 January 2016. One of the important components for Indonesia to face the MEA is the number of domestic entrepreneurs, because entrepreneurs have a big role in supporting the economy. However, it is unfortunate according to the data of Central Bureau of Statistics (BPS), the number of entrepreneurs in Indonesia is only 3.1\%, while other ASEAN country, such as Malaysia or Singapore is up to 5\%. Based on these problems the authors develop solutions in the form of integration of entrepreneurship education in elementary schools. Entrepreneurship education is important to be given considering the formation of entrepreneurial character needs to be fostered since the early age, so that the future of many emerging entrepreneurs Indonesia. In developing it, the author is based on Piaget's cognitive theory, where elementary children experience concrete operational phase, so that the development of entrepreneurship education is packed with concrete activities. With the writing of this work is expected to be a reference of entrepreneurship education methods in the elementary school and implicate the increasing number of entrepreneurs in Indonesia.
\end{abstract}

Keywords: Elementary School, Entrepreneurship Education

\section{INTRODUCTION}

The ASEAN Economic Community (MEA) has been officially implemented by the rest of countries in ASEAN on January 1st 2016. MEA is the momentum of free market among ASEAN citizens. Overseas products will be easily obtained with cheap price, this certainly makes the economic competition more fierce. In addition, the number of jobs in Indonesia will also be less because of the foreign citizenship that will apply for jobs. Whereas the Open Unemployment Rate (TPT) on February 2017 in Indonesia is quite a lot of 5.33 percent (BPS, 2017) [1].

Action is required to prepare or overcome it. One of the solutions is through the increasement of entrepreneurs in Indonesia. With a large number of entrepreneurial then the products that will be generated will be more and more and it is directly proportional to the amount of employment field. However, it is unfortunate because the number of entrepreneurs for Indonesia losing much compared to Malaysia or Singapore that amounted to $5 \%$. Based on the number of BPS data entrepreneur Indonesia only $3.1 \%$. With the least amount of entrepreneurs will have a direct impact on the economy, both microas well as macro. The number of jobless will stagnate or decrease if MEA takes place with a number of enterpreneurs who are still few. It is necessary to increase the number of entrepreneurs to face the MEA. The low number of entrepreneurs is believed to be the mindset of being a civil servant still inherent in Indonesian society. Fear of bankruptcy and entrepreneurial character that is not built are the main cause of people's thoughts. Based on these problems, the need for introduction of entrepreneurship early on which aims to shape the entrepreneurial character to children is needed. So leadership, optimistic and brave to take risks characters will be internalize. That's why, the authors develop entrepreneurship education in elementary school so that they are able to apply it in the future. There are two problems of the research, which are the definition of entrepreneurship education and learning models of enterprenurship in elementary school.

\section{METHODS}

This research is library research. According to Hasan (2002: 11) library research (literature research) is research conducted using literature (literature), either in the form of books, notes, or research reports from previous research. The data source of this research is document [2] . Document study is looking for data about things or variables in the form of notes or transcripts, books, newspapers, magazines (Arikunto, 2010: 275) [3]. Data 
collection techniques is to examine various sources such as books, research journals, articles, papers, newspapers, intenet or other information related to the title of research. After data collected then performed data analysis. Data analysis in this study is to analyze and synthesize the document to be reviewed and become a new idea in supporting the research results.

\section{DISCUSSION}

\subsection{The Definition of Enterpeneurship Education}

Entrepreneurship is a feature that can be observed in the actions of a person. Entrepreneurs in the fields of health, education and business basically work the same way, they work better, they do it differently than others (Drucker, 2007: 45) [4]. Entrepreneurship as a behavior can be demonstrated through dynamic, risky, creative and growthoriented responses that are an innovation process (Susilaningsih, 2015: 3) [5]. An entrepreneur is a person who sees opportunities. The definition of entrepreneurship here emphasizes on everyone who started a new business (Alma, 2011: 24) [6].

Entrepreneurship is a tool of life's view of wanting freedom in the financial need to create something new by using existing resources. To achieve this must be good at utilizing opportunities through business opportunities, appropriate risktaking management capabilities to achieve opportunities, and through communication skills and management expertise in mobilizing people, finances and material resources to produce projects well (Ranto 2007: 21) [7]. According to Suherman (2008: 13) entrepreneurship is basically the soul of someone who is expressed through the attitude and behavior of creative and innovative to do an activity [8]. The person who has the soul of course can do entrepreneurial activities or become entrepreneurial actors.

From some of the above understanding, it can be concluded that entrepreneurship is about the process of creating something different, which has added value through the sacrifice of time and energy with various social risks and get appreciated for something earned along with the emergence of personal powers of the results obtained.

With the development of entrepreneurship education is expected to provide some outcomes as follows:

1. The establishment of a set of mappings containing entrepreneurial values and indicators of entrepreneurial success of learners in each educational unit ranging from early childhood education to secondary and non formal education.

2. Appropriate design and examples of integration of entrepreneurship education in each educational unit ranging from the level of early education to secondary.

\subsection{Learning Models of Enterpreneurship Education in Elementary School}

Presidential Instruction No. 4/1995 on the National Movement of Socializing and Entrepreneurship Entrepreneurship, mandates to all Indonesian and nations to develop entrepreneurial programs [9]. The government is well aware that the business world is the backbone of the national economy, so it must be strived to be improved continuously.

Through this movement is expected that entrepreneurial character will be part of the work ethic of the Indonesian, so it can give birth to new entrepreneurs who are reliable, tough, and independent. The integration of entrepreneurship education in education is a momentum for the revitalization of the national policy to popularize the entrepreneurship, it is caused by largest number of open unemployed from the graduates of educational units at primary and secondary levels. Through the policy of the Ministry of National Education that includes the curriculum of entrepreneurship education in educational institutions (Depdiknas, 2005) [10]. The concept of entrepreneurship is integrated since students sit in elementary school to college. Entrepreneurship education equips learners to be independent and not oriented to job seekers but to job openers. Primary School or called the school age between 7-12 years. According Poerwati (2013: 118) thought elementary students can still be formed in accordance with the needs of the environment, so the mindset about the ideals of children to be entrepreneurs must be formed [11]. Some of the model used as the organizers of entrepreneurship value cultivation:

1. Integrated Model in Subject

Entrepreneurship education can also be integrated in the learning of each subject. Learning materials related to norms or values on is needed to be developed, explored, linked to the context of everyday life. Thus, entrepreneurial educationoriented learning is not only at the cognitive level, but it touches on internalization, and real practice in the lives of everyday learners in society. The advantage of this model is that all teachers could participate in the responsibility of cultivating the values of entrepreneurship education to students. Understanding the value of entrepreneurial attitudes 
in learners is not only informative-cognitive, but applied to each subject. The weakness of this model is the cultivation of entrepreneurship education that is only limited to values and attitudes such as honest, disciplined, competive and others, there is no basic planting for entrepreneurship.

2. Learning Model Through extracurricular activities

Extra curricular activities that have been held by schools is one of the potential media for character development including the character of entrepreneurship and the improvement of academic quality of learners. Extra Curricular Activities are out-of-school educational activities to assist the development of learners according to their needs, potentials, talents, and interests through activities that are specifically organized by educators and / or education personnel who are capable and authorized in the school. Extra curricular activities are expected to develop the ability and sense of social responsibility, as well as the potential and achievement of learners.

The advantage of this model is the student really get value through concrete experiences. Experience will be more embedded when it's compared with hearing information in classroom. Learners of this model is no fixed structure within the framework of education and teaching in school and takes more time. Student-learners more involved in digging the values of life and learning are more encouraging. The weakness of this model is no fixed structure within the framework of the education and teaching in school and need more time. This model also demands creativity and understanding of the needs of the participants Educated in depth. This kind of activity can not only be held once a year or twice but must be repeated many times.

3. Cultural Model, Habitual Value in All Activities and School Atmosphere

The cultivation of entrepreneurship education values can also be embedded through in all activities and school suits. Culture will create a habit. To cultivate the values of entrepreneurship education schools need to plan a culture and habituation activities. For younger learners, habituation is very important. Because with habituation that eventually an activity will belong to learners in the future. Good habituation will form a good human personality as well.

Conversely, bad habits will form a bad personality as well. Based on the habituation that learners are accustomed to obey the rules that is in school and community, after getting good education habituation in school. It will influence also carried in daily life at home and until adult later. Inculcate good habits is not easy And sometimes takes a long time to instill the values of entrepreneurship education through habituation in learners but something that has become a habit difficult to change too.

4. Model of entrepreneurship subject

In addition to using an Integrated Model in Subject, values of entrepreneurship education could be given into a subject. It can be add into local content subject that is each region has a different local content based on the regional potential. Local entrepreneurial subcontracts are not entirely about entrepreneurship, but cultivation of values, attitudes and basic entrepreneurship, such as local TTGA and KPDL subject, in local content indirectly internalize entrepreneurship education in agriculture, farming and socializing with the community.

The advantage of this model is the students directly practice activities in local content so as to have provision for entrepreneurship, while the weakness of this model is the local content of each region is different so there is possibility not all existing local content internalize the value of entrepreneurship education.

\section{Combined Model}

The combined model means using a combination of a integrated learning model and Learning Model Through extracurricular activities. This model can be implemented both in collaboration with teams by teachers and in collaboration with outsiders. The advantage of this model is that all teachers are involved.. Children will recognize the values of life by informatively and reinforced by experience through well-planned activities. The weakness of this model is demanding the involvement of many parties and a lot of time for coordination. In addition, not all teachers have competence and skills to embed the values of entrepreneurial education

\section{SUMMARY}

MEA has been officially enacted, it is necessary to prepare Indonesia in facing Open Unemployment Rate (TPT) problem and number of entrepreneurs which only reach $3.1 \%$. One of the solutions offered is entrepreneurship education at the Elementary School level. Entrepreneurship is entrepreneurship is about the process of creating something different, which has added value through the sacrifice of time and energy with various social risks and get appreciated for something earned along with the emergence of personal powers of the results obtained. There are several models of entrepreneurship education in elementary school, among others, are integrated model in subject, learning model through extracurricular activities, cultural model, habitual value in 11 activities and school atmosphere, model of entrepreneurship 
subject, combined model. Each model has its own weaknesses and advantages. Withentrepreneurship education in elementary school is expected that children have understanding and entrepreneurial character since small so that they are able to apply it in the future.

\section{ACKNOWLEDGEMENTS}

The researcher would like to thank Farid Ahmadi, M.Pd., Ph.D. as supervisor who was willing to guide this paper and the preparation of this paper has been supported in part by Department of Elementary School Teacher Education, Universitas Negeri Semarang.

\section{REFERENCES}

[1] BPS. (2017). Keadaan Ketenagakerjaan Indonesia Fabruari Tahun 2017. Diakses tanggal 1 Mei 2017 dari ntb.bps.go.id/webs/brs_ind/brsInd 20170505143137.pdfv

[2] Hasan, M. Iqbal. 2002. Pokok-Pokok Materi Metodologi Penelitian. Jakarta: Ghalia Indonesia.

[3] Arikunto. 2010. Prosedur Penelitian. Suatu Pendekatan Prakti. Jakarta: Rineka Cipta.
[4] Drucker, Peter F. (2007). Innovation and Entrepreneurship: Practice and Principles. Oxford:Butterworth-Heinemann.

[5] Susilaningsih. (2015). Pendidikan Kewirausahaan di Perguruan Tinggi: Pentingkah untuk Semua Profesi?. Jurnal Ekonomia dan Bisnis Vol 2 Nomor 1. E-ISSN 2460-1152.

[6] Alma. (2011). Manajemen Pemasaran dan Pemasaran Jasa. Bandung : Penerbit Alfabeta.

[7] Ranto. (2007). Korelasi antara Motivasi, Knowledge of Entreprenurship dan Independensi dan The Entrepreneur's Performance pada Kawasan Industri Kecil, Manajemen Usahawan Indonesia, LMFE-UI, Jakarta.

[8] Suherman. (2008). Desain Pembelajaran Kewirausahaan. Bandung: Alfabeta.

[9] Instruksi Presiden Nomor 4 Tahun 1995 Tentang gerakan Nasional Memasyarakatkan dan Membudayakan Kewirausahaan

[10] Departemen Pendidikan Nasional. (2005). Peraturan Pemerintah Republik Indonesia Nomor: 19 Tahun 2005 Tentang Standar Nasional Pendidikan. Jakarta

[11] Poerwati, Endah Loeloek, dkk. (2013). Panduan Memahami Kurikulum 2013. Jakarta: Prestasi Pusaka. 